Blane, G. ( $\left.7_{7} 85\right)$. Observations on the Diseases Incident to Seamen. London: J. Murray.

Lind, J. (1753). A Treatise of the Scurvy, Ist ed. Edinburgh: Sands, Murray and Cochran for A. Kincaid and A Donaldson.

Lind, J. (1757). An Essay on the Most Effectual Means of Preserving the Health of Seamen in the Royal Navy, London: A. Millar.

Lind, J. (1768). An Essay on Diseases Incidental to Europeans in Hot Climates. London: T. Becket and P. A. De Hondt.

Simon, J. (1890). English Sanitary Institutions. London: Cassell and Co.

\title{
The Sheffield Experiment on the Vitamin C Requirement of Human Adults*
}

\section{By H. A. Krebs, Medical Research Council Unit for Research in Cell Metabolism, Department of Biochemistry, University of Sheffield}

In 1938 the League of Nations Technical Commission on Nutrition estimated the daily vitamin $\mathrm{C}$ requirement of human adults at $30 \mathrm{mg}$ (League of Nations Health Organization: Technical Commission on Nutrition, 1938). In 1943 the (U.S.A.) National Research Council Committee on Food and Nutrition recommended an allowance of $75 \mathrm{mg}$ (National Research Council: Food and Nutrition Board, 1943). Some authorities, e.g. Zilva (194r, 1944) put the daily requirements much below $30 \mathrm{mg}$.

These were the main data on which dietary planning had to be based during the war years. The divergences in the estimates arose from the different standards used in assessing the requirement. The high values were based on studies of the saturation of the body with vitamin $\mathrm{C}$, whereas the lower values were inferred from observations on the prevention and cure of the clinical manifestations of scurvy. The differences were also an indication of the lack of accurate information, and in 1944 Professor R. A. Peters suggested to the Medical Research Council that it would be worth while obtaining additional information on the vitamin $\mathrm{C}$ requirements of human adults by a trial on human volunteers who had offered themselves for this kind of investigation at the Sorby Research Institute at Sheffield. Professor Peters's suggestion was accepted and the Vitamin C Subcommittee of the Medical

* This is a summary of the main aspects of the trial conducted by the Vitamin C Subcommittee of the Accessory Food Factors Committee of the Medical Research Council. Members of the Committee were R. A. Peters (Chairman), K. H. Coward, H. A. Krebs, L. W. Mapson, L. G. Parsons, B. S. Platt, J. C. Spence, J. R. P. O'Brien (Secretary). Others taking part were A. E. Barnes, W. Bartley, I. M. Frankau, G. A. Higgins, E. M. Hume, J. Pemberton, G. L. Roberts, H. Scarborough, H. R. Vickers, J. Waterlow and W. J. W. Ferguson. A full account of the trial is published by H.M. Stationery Office (Bartley, Krebs \& O'Brien, I 953). This Report includes reproductions of colour photographs of the pathological conditions seen during the trial. (See also Medical Research Council: Vitamin C Subcommittee of the Accessory Food Factors Committee, I948.)

The colour plates I to VI illustrate some of the clinical findings made during the trial.

The author is indebted to the Controller of H.M. Stationery Office for permission to produce this summary and for the use of illustrations taken from the Report. 
Research Council under the chairmanship of Professor Peters was entrusted with the task of designing and conducting the trial. This was carried out at Sheffield from October 1944 to February 1946 . The main plan was to induce scurvy by a vitamin C-deficient diet and to establish the minimum dose of the vitamin that cures scurvy. A subsidiary aim was to study the clinical signs and symptoms of scurvy and to correlate them with laboratory findings. Owing to the limited number of volunteers, the scope and design of the trial were bound to be restricted.

Nineteen men and one woman, aged $2 \mathrm{I}-34$, volunteered for the experiment. They lived a normal life without strenuous physical work. Their basal diet was designed to be as low as possible in vitamin $\mathrm{C}$ but complete in every other respect. It was sufficiently varied to be acceptable. From chemical analyses it was calculated that on the average a volunteer obtained not more than I $\mathrm{mg}$ vitamin $\mathrm{C}$ daily from the diet.

To obtain base-line data the trial began with a preliminary period, in most cases of 6 weeks, on a complete diet including about $70 \mathrm{mg}$ vitamin $\mathrm{C}$ daily. At the end of the period all the volunteers were given the basal deficient diet and divided into three groups, ten having no supplements, seven $10 \mathrm{mg}$ of vitamin $\mathrm{C}$ daily, and three $70 \mathrm{mg}$ vitamin $\mathrm{C}$ daily. The group receiving $70 \mathrm{mg}$ was intended to serve as a positive control and the group receiving Io $\mathrm{mg}$ as a prophylactic test. The volunteers did not know to which group they belonged, nor did the physicians responsible for the clinical investigation. All the volunteers were daily given seven supplementary tablets of identical taste and appearance, some containing vitamin $\mathrm{C}$, the others being dummies. Investigations, made on the volunteers at regular intervals, included general clinical examinations, chemical analyses of blood and urine, haematological examinations, capillary-fragility tests, capillaroscopy, radiography, electrocardiography, studies of fatigue, and studies of experimental wounds.

\section{Development of signs of deficiency}

The clinical examinations, by inspection and physical methods, revealed no definite changes during the first 17 weeks of deprivation. The first changes which retrospectively were recognized as significant were enlargement and keratosis of the hair follicles in one volunteer, particularly on the outer aspect of the upper arm. After 21 weeks six of the ten deprived volunteers had developed follicular changes, and after 26 weeks all had done so. The main areas affected were the upper arms, backs, buttocks, back of thighs, calves and shins. In all of them except one the enlarged hair follicles eventually became haemorrhagic.

Examination with the skin microscope showed that the initial change was the plugging of follicles by horny material in which the hair was coiled or looped. A few weeks later the enlarged follicles turned red. Under the microscope this redness presented itself as congestion and proliferation of the blood-vessels round the hair follicles. The colour gradually deepened and within another week or two the enlarged hair follicles became haemorrhagic, the red colour turning dark purple 
and no longer disappearing on compression; at this stage many red cells could be seen outside the vessels.

After 26 weeks of deprivation, six of the ten volunteers, and 9 weeks later nine of the ten, had numerous haemorrhagic follicles. In general it was on the legs that the follicles showed the greatest tendency to become haemorrhagic. No subjective sensations accompanied the appearance of the haemorrhages.

As the development of enlarged and haemorrhagic hair follicles progressed, five of the ten deprived volunteers showed a very pronounced exacerbation of the acne present in a mild form at the start of the experiment. The papules became more numerous after about 22 weeks; they increased in size and later became bright red and eventually haemorrhagic. The other five deprived volunteers who had no acne at the start remained free throughout the experiment.

Other changes generally noted during the period of deprivation were in the gums. The earliest signs were tiny haemorrhages in the tips of the interdental papillae, and swelling, seen first after 26 weeks of deprivation. About to weeks later, nine of the ten deprived volunteers had developed abnormalities of the gums, gross in two cases, less advanced but definite in five other cases, and slight in the remaining two cases.

Another striking observation, in agreement with the old accounts of scurvy, was made after 30 weeks in six of the ten deprived volunteers. It concerned the behaviour of the scars of experimental wounds that had been made to study wound healing. Scars of wounds made earlier during the trial, whose healing had proceeded normally, became red and livid. New wounds made at the stage of pronounced haemorrhagic scurvy showed a reduced tendency to heal.

Some important abnormalities were observed in single cases. One man developed effusions into both knee joints and ecchymoses of the leg during the 3 oth week of deprivation after a long walk. Another was taken ill 4 weeks later, i $9 \mathrm{~h}$ after heavy physical exercise. He had severe pain in the lower sternal region, and became dyspnoeic and cyanosed. The pulse was rapid and the blood pressure low. The clinical picture was that of an acute cardiac emergency. He was immediately admitted to hospital and dosed with vitamin $\mathrm{C}$. The lower sternal pain, which at first had increased in intensity, passed off after $9 \mathrm{~h}$. The electrocardiogram showed high ST levels in leads I and II. A radiogram of the chest showed no abnormality. Eighteen days later another deprived volunteer complained of a sudden constrictive pain in the chest. Physical examination revealed a systolic murmur which had not been heard before, and the electrocardiogram showed a partial heart-block, the P-R interval being 0.32 sec. Before the experiment the electrocardiogram had been normal with a P-R interval of $0.20 \mathrm{sec}$. It was thought necessary to treat this volunteer immediately with large doses of vitamin $C$. The chest pain and the systolic murmur disappeared within $24 \mathrm{~h}$, but during the following months the P-R interval showed variable periods between 0.13 and $0.32 \mathrm{sec}$. depending on posture, breathing, administration of drugs, and other factors.

The pathological process underlying this cardiac emergency is bound to remain uncertain. The older records of scurvy contain many references to sudden death. 
Lind ( 1757, p. I37) writes: 'Persons that appear to be but slightly scorbutic, are apt to be suddenly and unexpectedly seized with some of its worse symptoms. Their dropping down dead upon an exertion of their strength, or change of air, is not easily foretold'. As these incidents occur at a stage when multiple skin petechiae are the main clinical manifestation of scurvy, and when general fitness still appears to be fairly good, it is not improbable that a haemorrhage at a critical point of the conducting system of the heart forms the basis of the cardiac syndrome.

Negative findings during the period of deprivation included no significant change in body-weight, no increased incidence of infection, and no change in the appearance of the capillaries of the nail bed and of the conjunctivae. Dark adaptation, haemoglobin concentration, red-cell count, total and differential leucocyte counts, platelet count, and bleeding time remained normal. There were no complaints of general pains or weakness. The capillary-resistance tests of Hess (I 920 , p. 2I2) and of Göthlin (I93I) showed no consistent trends throughout the period of deprivation.

To sum up, the clinical course of the development of scurvy was fairly uniform in the ten volunteers: no clinical signs for about I7 weeks; the first sign, after 17-21 weeks, was hyperkeratosis of the hair follicles; after 26-34 weeks perifollicular haemorrhages occurred and after $30-3^{8}$ weeks swelling and haemorrhages of the gums. Exacerbation of acne, not apparently hitherto recognized as a sign of scurvy, began after 22 weeks.

Like all the other single clinical signs of scurvy, neither hyperkeratosis nor congestion of the hair follicles is a specific sign, and the occurrence of gradual development of either of them in a person does not necessarily indicate lack of vitamin C. They occur in many people 'saturated' with vitamin C. Deficiency in this vitamin is only one of a variety of causes that can evoke them. In the Sheffield experiment the appearance and disappearance of the skin changes reflected the intake of vitamin $\mathrm{C}$, and this proved beyond doubt that they were the early stages of the typical haemorrhagic spots of scurvy. It is noteworthy that vitamin A deficiency, in a similar trial, did not lead to hyperkeratosis (Hume \& Krebs, 1949).

The gum lesions appeared always after the skin lesions. Though this may not always be true of scurvy, it might nevertheless be a useful diagnostic pointer in deciding on the cause of gum lesions of doubtful origin.

Many signs listed as scorbutic in the classical description of the disease, e.g. pallor, dryness of the skin, anaemia, and night-blindness, were not observed. It is probable that classical scurvy was often a multiple deficiency.

\section{Effects of vitamin $C$ supplements}

In the seven volunteers receiving a supplement of $\mathrm{I}$ o $\mathrm{mg}$ vitamin $\mathrm{C}$ daily no abnormalities were noted during the first $\mathrm{I} 60$ days of the experimental period. It was then decided that four of the volunteers should continue with the Io mg supplement and three of them be deprived of it, the object being to ascertain whether signs of deficiency would develop quickly on withdrawal of the supplement. 


\section{PLATE I}

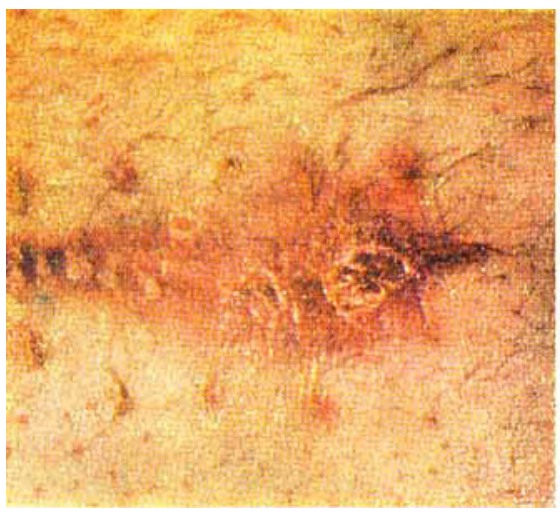

FIG. A. Drake, 26.6.45. Haemorrhagic and infiltrated wound. 226 days depletion. (Natural size.)

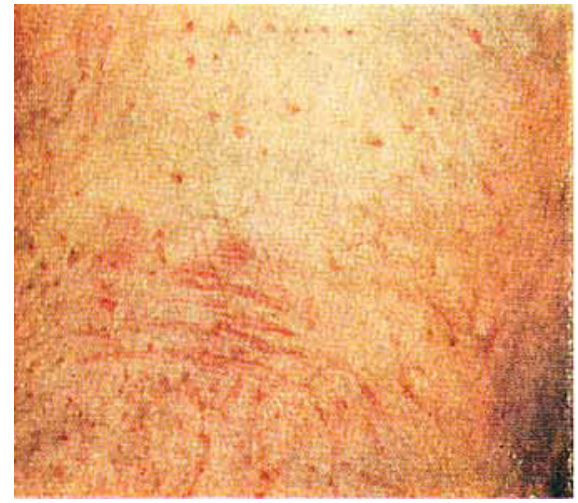

FIG. C. Drake, 3.7.45. Haemorrhagic patch on back of knee. 233 days' depletion. ( $x$

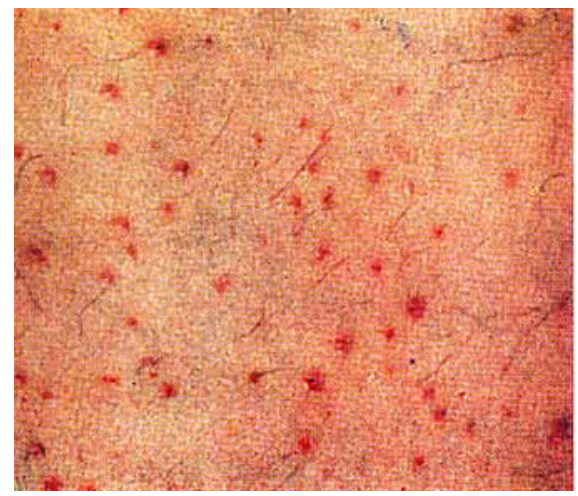

FIG. E. Hudson, 31.7.45. Haemorrhagic follicles on back of right thigh. 261 days' depletion. (About natural size.)

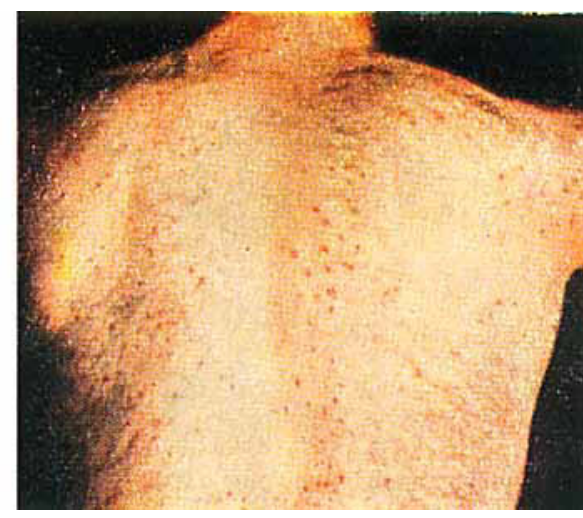

FIG. B. Drake, 3.7.45. Acneiform eruption on the back. 233 days depletion. $\left(\times \frac{1}{6}\right)$

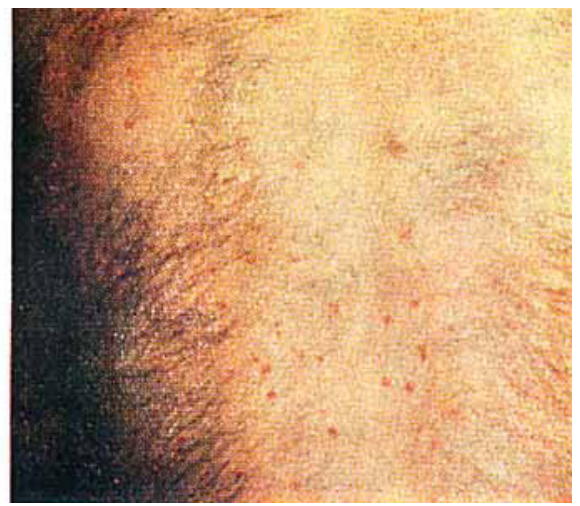

FiG. D. Drake, 5.11.45. State of acneiform eruption after 125 days' dosing. ( $\left.X \frac{1}{5}\right)$

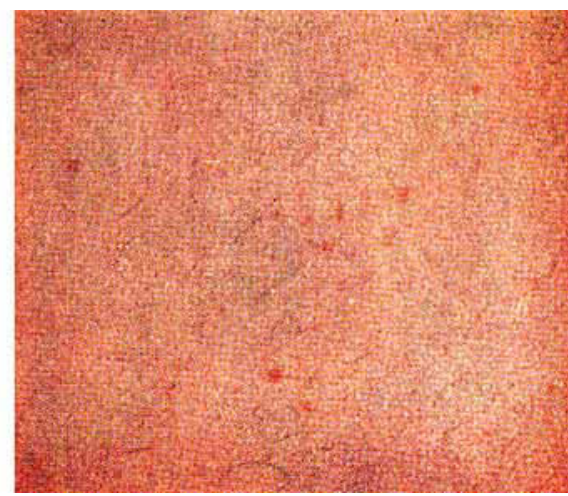

FIG. F. Hudson, 16.10.45. Same site of thigh as Fig. E after 78 days' dosing with $10 \mathrm{mg}$ vitamin $\mathrm{C}$ daily showing improvement. (Almost natural size.) 


\section{PLATE II}

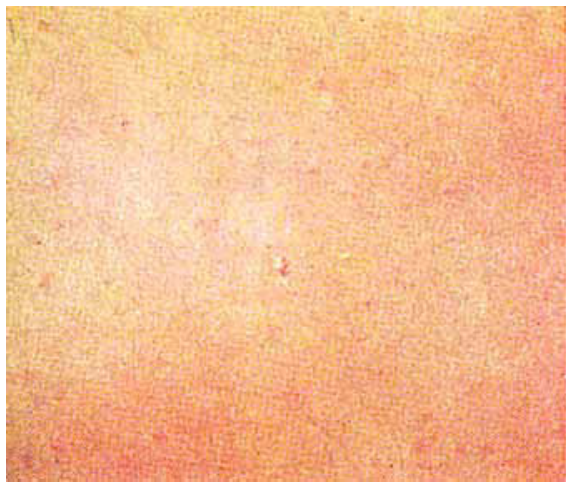

FIG. A. Milburn, 18.4.45. Early stage of congested keratotic hair follicles on upper arm. 151 days' depletion. (Natural size.)

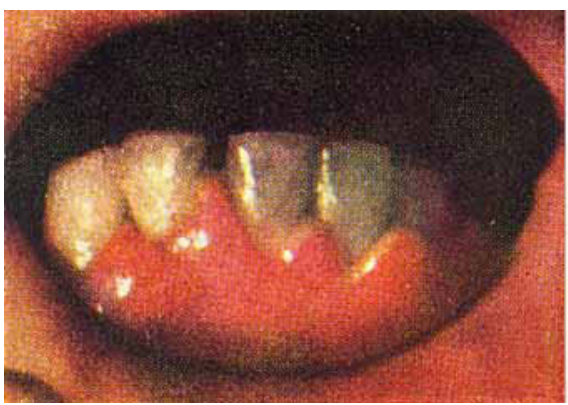

FIG. C. Robinson, 1.8.45. Increased swelling of gums of lower jaw after 6 days' dosing with $10 \mathrm{mg}$. vitamin $\mathrm{C}$ daily. $(\times 1 \cdot 4)$

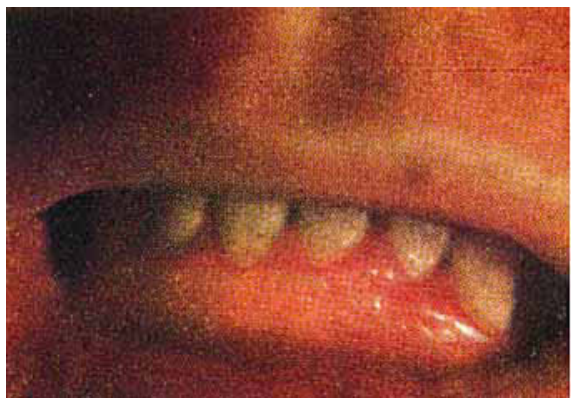

FIG. E. Robinson, 14.11.45. Almost normal gums. 111 days' dosing with $10 \mathrm{mg}$. vitamin $\mathrm{C}$ daily. $(\times 1.4)$

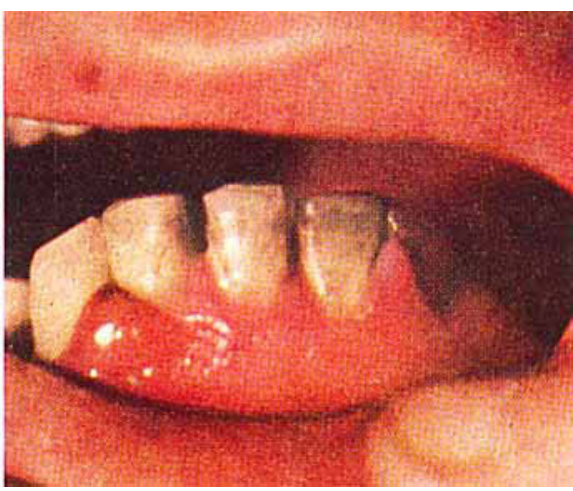

FIG, B. Robinson, 10.7.45. Swollen interdental papillae. 237 days' depletion, $(\times \quad 1 \cdot 4)$

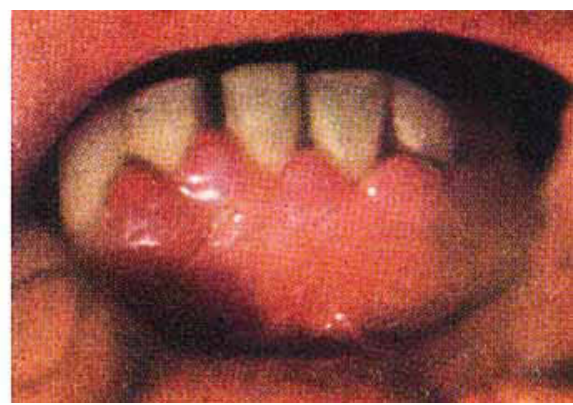

FIG. D. Robinson, 8.8.45. Gum colour less red, but swelling unchanged. 13 days' dosing.

$$
(\times 1 \cdot 4)
$$

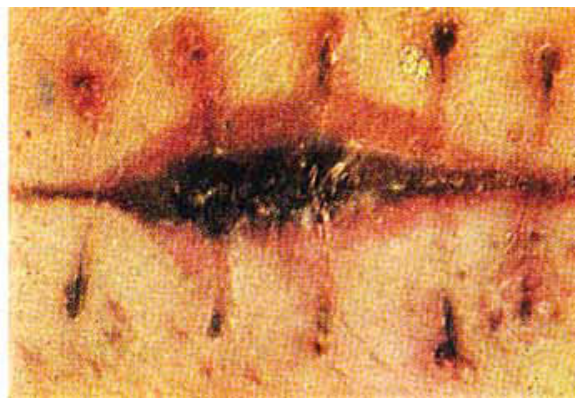

Fig. F. Sanderson, 12.6.45. Haemorrhagic scar of wound excised on 28.5.45. 212 days' depletion. $(\times 2)$ 


\section{PLATE III}

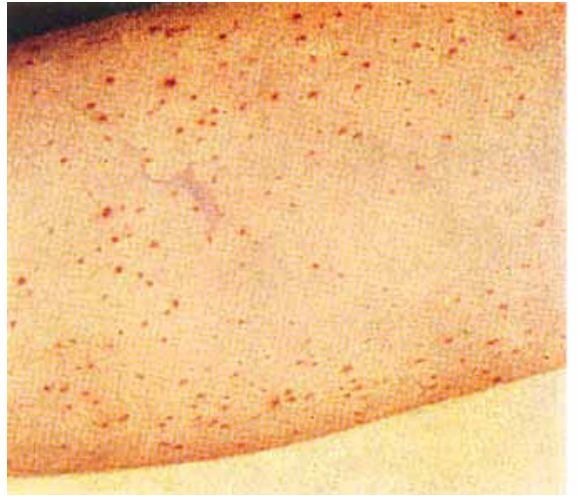

FrG. A. Sanderson, 24.7.45. Numerous perifollicular haemorrhages on back of calf. 254 days' depletion. $\left(\times \frac{1}{3}\right)$

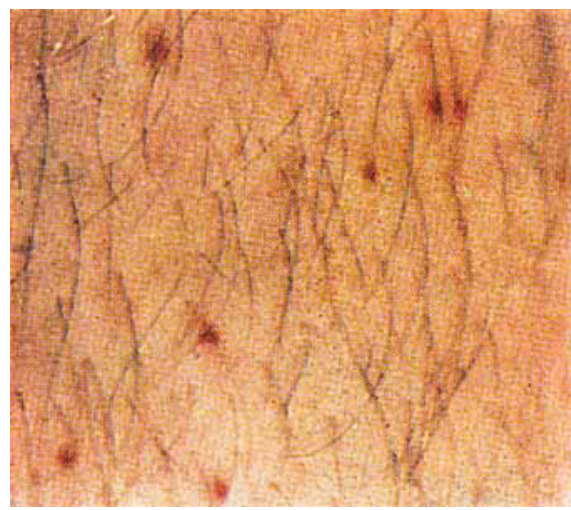

FIG. C. Williams, D., 17.5.45. 186 days' depletion, Right calf. Haemorrhagic follicles. (Natural size.)

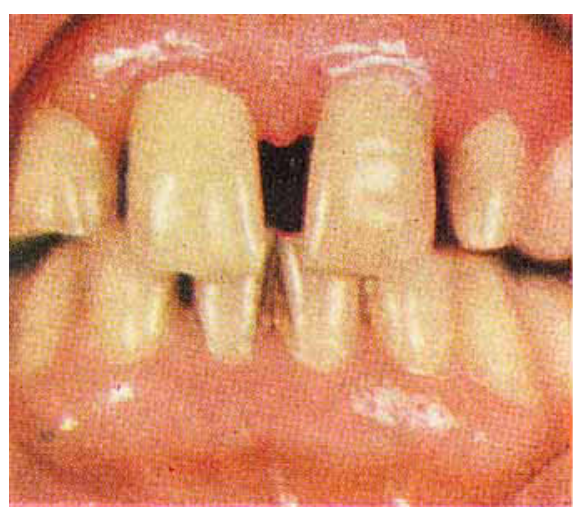

Fig. E. Wodeman, 22.12.44. Normal gums at initial stage. $(\times 1.7)$

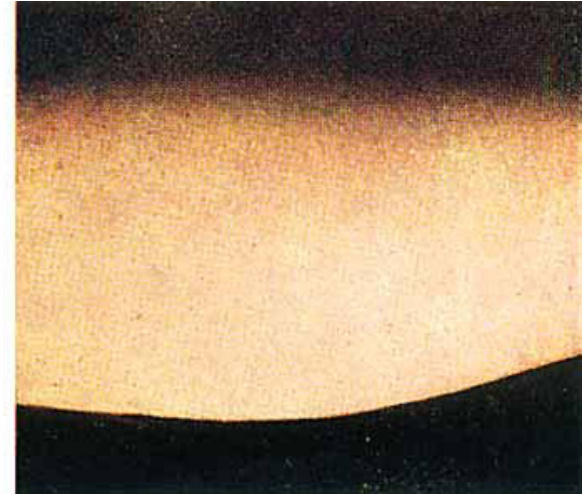

FiG. B. Sanderson, 5.10.45. 71 days' dosing. Back of calf. Disappearance of haemorrhages. $\left(x \frac{1}{5}\right)$

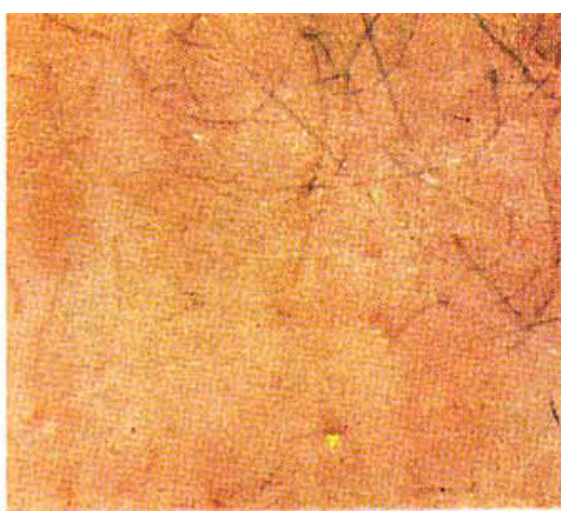

FIG. D. Williams, D., 23.5.45. Same area as in Fig. C. 7 days later after dosing with $500 \mathrm{mg}$. vitamin $C$ daily. Disappearance of haemorrhagic follicles. (Natural size.)

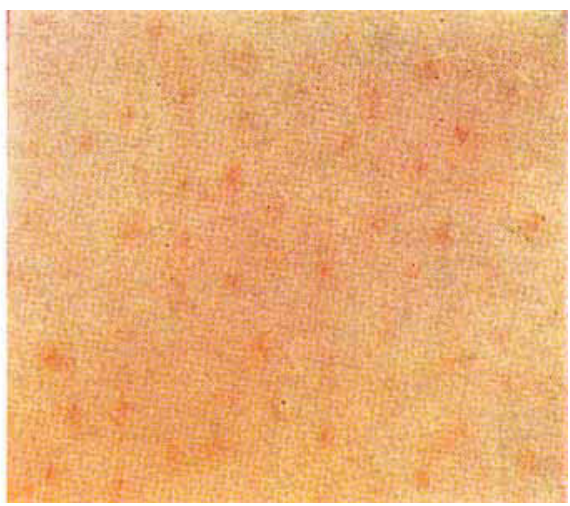

FIG. F. Wodeman, 11.5.45. Congested follicles on thigh. 180 days' depletion. (Natural size.) 


\section{PLATE IV}

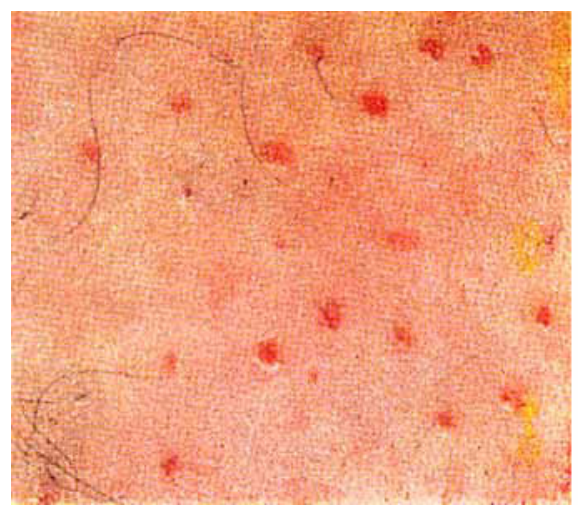

Fig. A. Wodeman, 30.5.45. Early haemorrhagic follicles on right calf. 199 days' depletion. $(x \mid .25)$

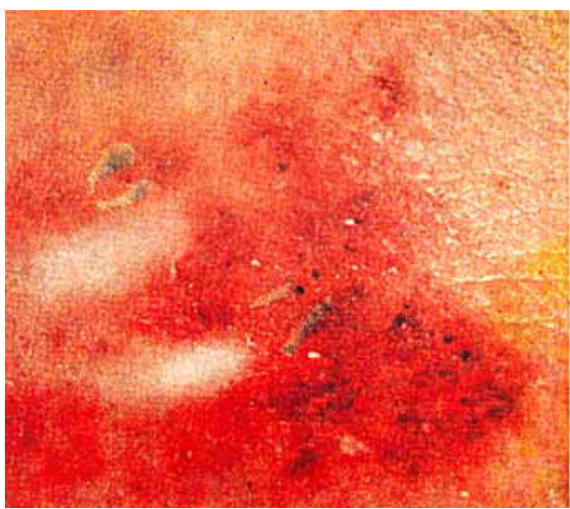

FIG. C. Wodeman, 30.5.45. Eczematous haemorrhagic patch on left ankle. 199 days' depletion. $(\times 1 \cdot 25)$

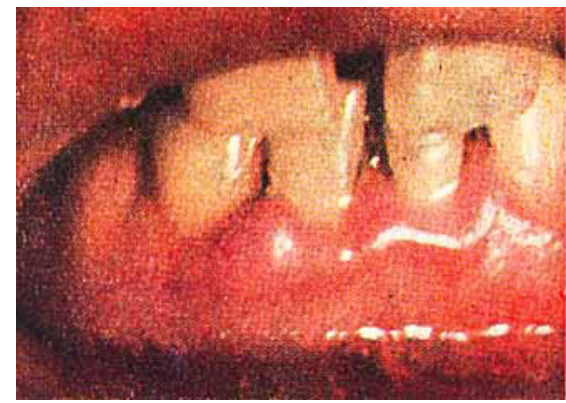

Fig. E. Wodeman, 7.6.45. Swelling and discoloration of interdental papillae. 207 days' depletion. $(\times 1 \cdot 5)$

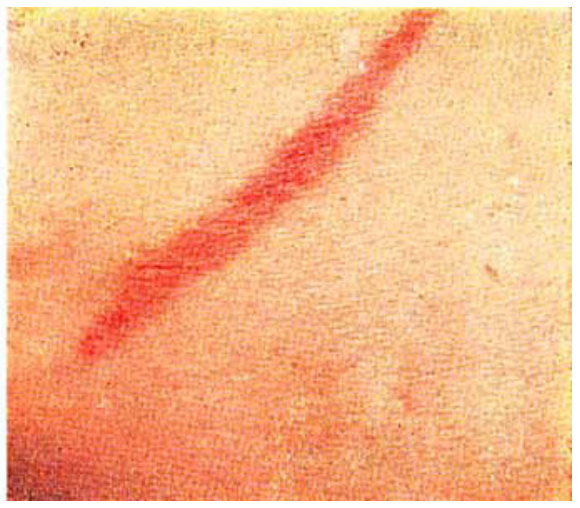

Fig. B. Wodeman, 30.5.45. Haemorrhage following capillary filtration test, according to Landis and Gibbon (1933); this began to show itself half an hour after the end of the test; the bruise consisted of numerous punctate haemorrhages. 199 days' depletion. $(\times 1 \cdot 3)$

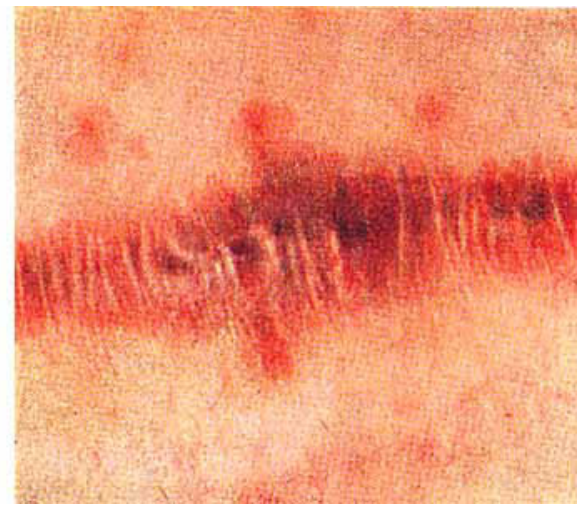

FIG. D. Wodeman, 12.6.45. Purple and swollen scar of wound made on 22.2.45, which had healed. 212 days' depletion. ( $\times 2$ )

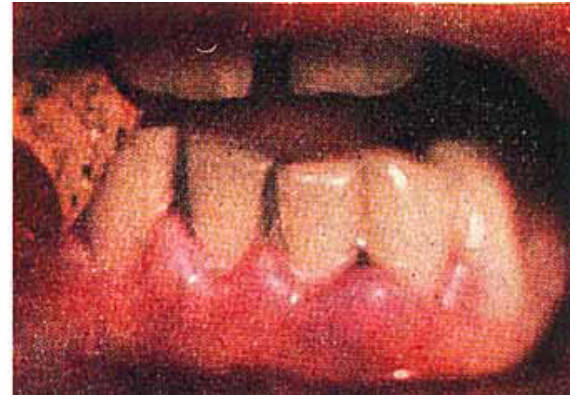

FIG. F. Wodeman, 18.6.45. Increased swelling and discoloration of interdental papillae; the surface tissue is covered with a whitish film. 218 days' depletion. $(\times 1 \cdot 5)$ 


\section{PLATE V}

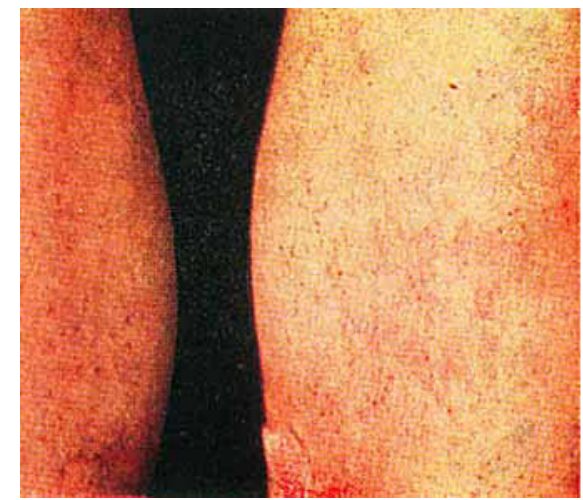

Fig. A. Wodeman, 18,6.45. Haemorrhagic follicles on legs. 218 day's depletion. ( $\left(\frac{1}{4}\right)$

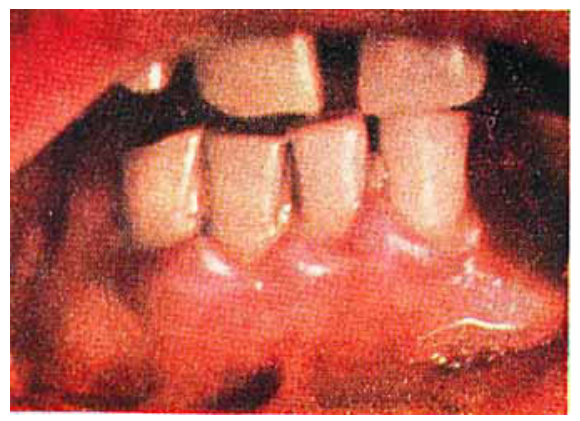

Fig. C. Wodeman, 2.7.45. Gums, less bluish coloration, but still swollen after 8 days' dosing with $10 \mathrm{mg}$. vitamin $C$ daily. $(\times 1.5)$

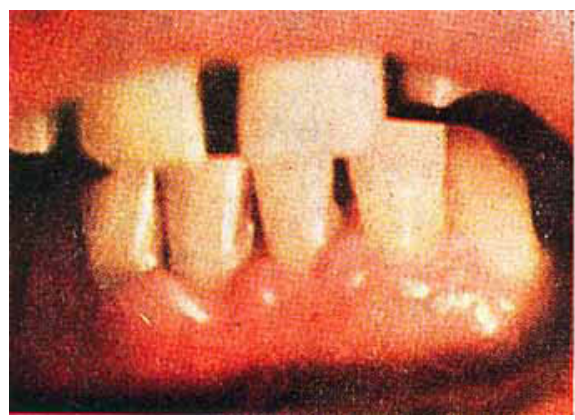

FIG. E. Wodeman, 10.7.45. Gums, less swollen; disappearance of blue colour after 16 days' dosing. ( $\times 1.5)$

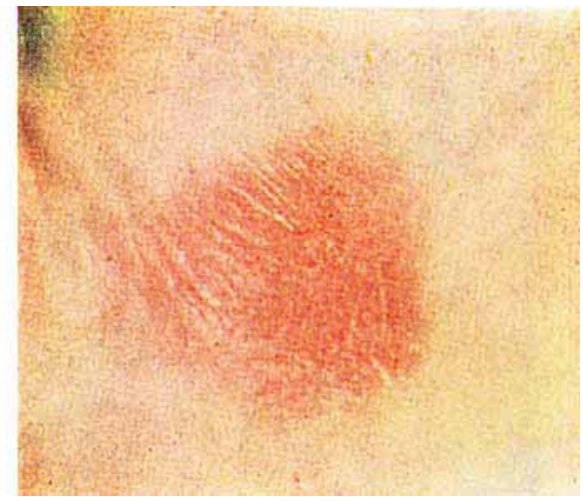

Fic. B. Wodeman, 3.7.45. Eczematous patch on left ankle after 9 days dosing; now less brightly red compare Plate IV Fig. C). ( $\therefore 1.25)$

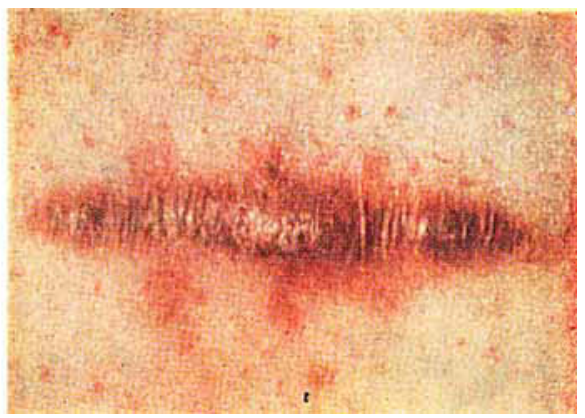

FIG. D. Wodeman, 3.7.45. Same wound scar as in Plate IV Fig. D after 9 days' dosing. Fading of purple coloration. $(\times 2)$

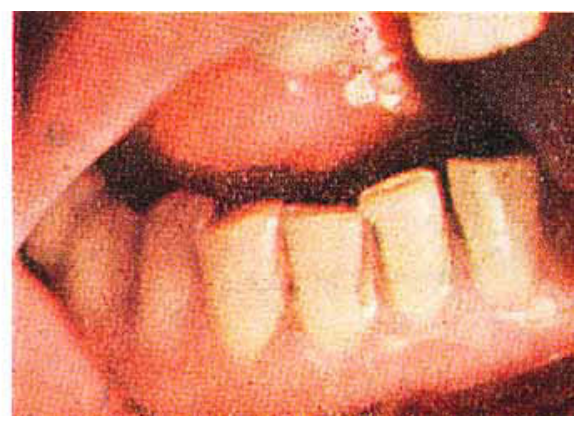

FIG. F. Wodeman, 4.10.45. Gums normal after 102 days' dosing. $(\times 1.5)$ 


\section{PLATE VI}

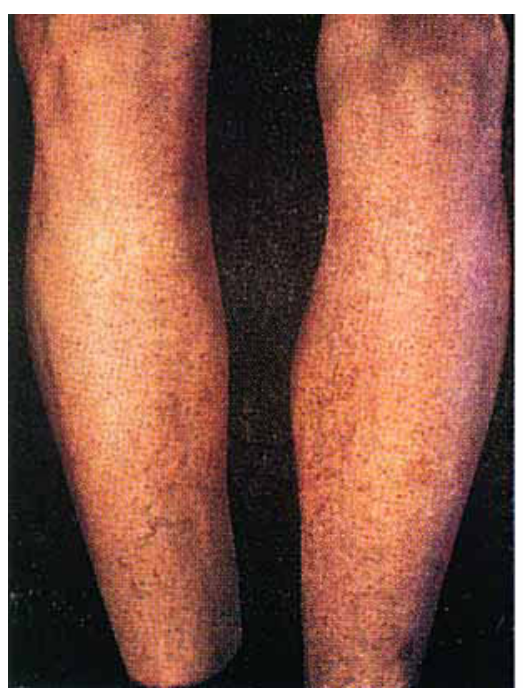

Fig. A. Wodeman, 3.7.45. Fading perifollicular haemorrhages after 9 days' dosing. $\left(x \frac{1}{5}\right)$

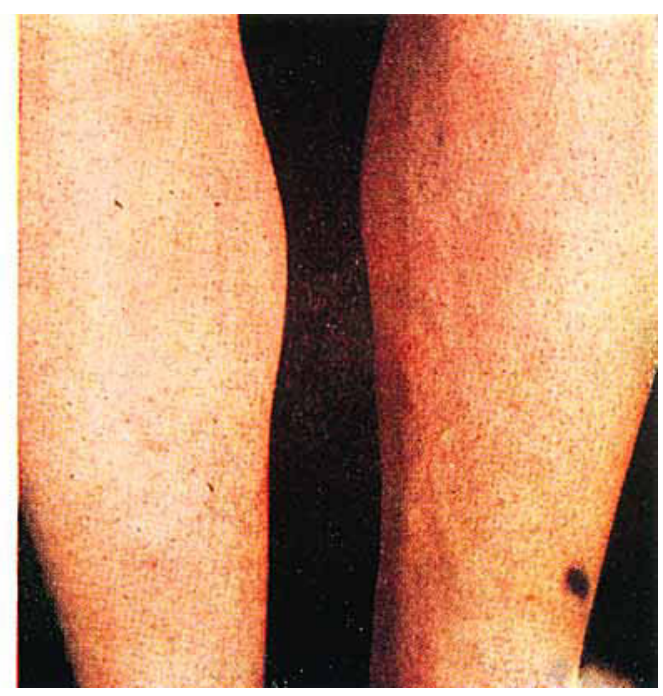

FIG. B. Wodeman, 10.7.45. Reduction in number, and change of colour to brown, of follicular haemorrhages on front of legs after 16 days' dosing. $\left(\times \frac{1}{3}\right)$

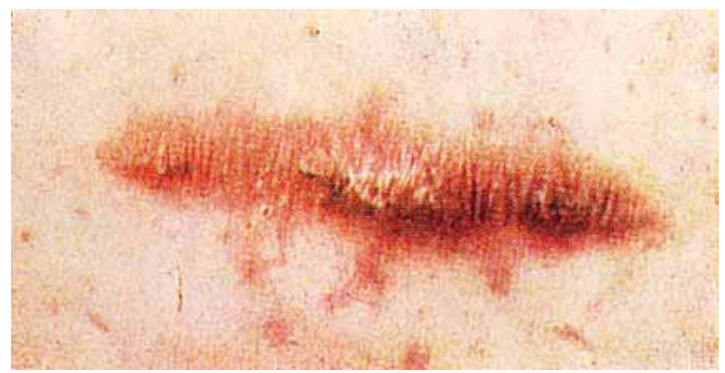

FIG. C. Wodeman, 10.7.45. Same wound scar as in Plate IV Fig. $D$ and Plate V Fig. D after 16 days' dosing; colour now normal. $(\times 1.25)$ 
Three of the four volunteers who received ro $\mathrm{mg}$ continued for another 264 days, and one abandoned the experiment after another 92 days. No abnormalities were recorded.

The second group of three volunteers had no supplement for $7 \mathrm{I}$ days, broken in one case by a 26-day period on a supplement of to mg. Again no definite signs of deficiency developed. To sum up, a prophylactic dose of $10 \mathrm{mg}$ vitamin C daily gave complete protection from clinical scurvy for periods up to 424 days.

The three volunteers who served as positive controls for 300,326 and 331 days and received $70 \mathrm{mg}$ vitamin $\mathrm{C}$ daily also showed no abnormalities.

\section{Curative effects of various doses of vitamin $C$}

Seven deprived volunteers, all showing unequivocal signs of scurvy-multiple skin haemorrhages and gum lesions-were available for dosing tests. In choosing the dose the intention was to give the smallest dose likely to produce a cure within a reasonable time but to aim too low rather than too high, since the dose could be increased later if necessary. A daily dose of $10 \mathrm{mg}$ was chosen and given to six of the seven volunteers. The seventh received $20 \mathrm{mg}$ because this volunteer was not available for long.

The response to the dose of $10 \mathrm{mg}$ followed the same pattern in all six cases. Within a week haemorrhages into the perifollicular region ceased, and within $\mathrm{x}$ or 2 weeks the older haemorrhages began to lose their dark purple colour and gradually faded. Within a month the hair in most of the follicles uncoiled, lifting out the plug. The dilation and congestion of the capillaries round the hair follicles disappeared, and within 7-9 weeks the skin appeared normal except for a slight brown pigmentation at the site of the former haemorrhages.

The liability to haemorrhage in the wound tissue and the failure of the wounds to heal disappeared as the follicular eruptions regressed. The wound haemorrhages disappeared within 2 months, the original blue and purple colour gradually giving way to a pure red, pink, and finally pale brown, and changes in the appearance of the wounds indicated improved healing.

The acneiform papules likewise regressed to the pre-experimental state, though in most cases somewhat more slowly than the other skin signs. The initial state was regained within $10-18$ weeks.

The gum lesions did not respond as promptly to dosing as the follicular skin lesions. When improvement began, the first sign was a change from livid blue to bright red, followed by the normal pink. Slowly the swelling decreased and the consistency of the gums improved, restoration being complete within IO-I4 weeks.

In brief, a dose of $10 \mathrm{mg}$ daily was followed in all cases by a gradual disappearance of the clinical manifestations of scurvy.

\section{Vitamin $C$ content of the blood}

Before the clinical observations are discussed in relation to the vitamin $\mathrm{C}$ requirement, reference should be made to some laboratory findings. Vitamin $\mathrm{C}$ determinations were made at weekly or fortnightly intervals on blood taken from the 


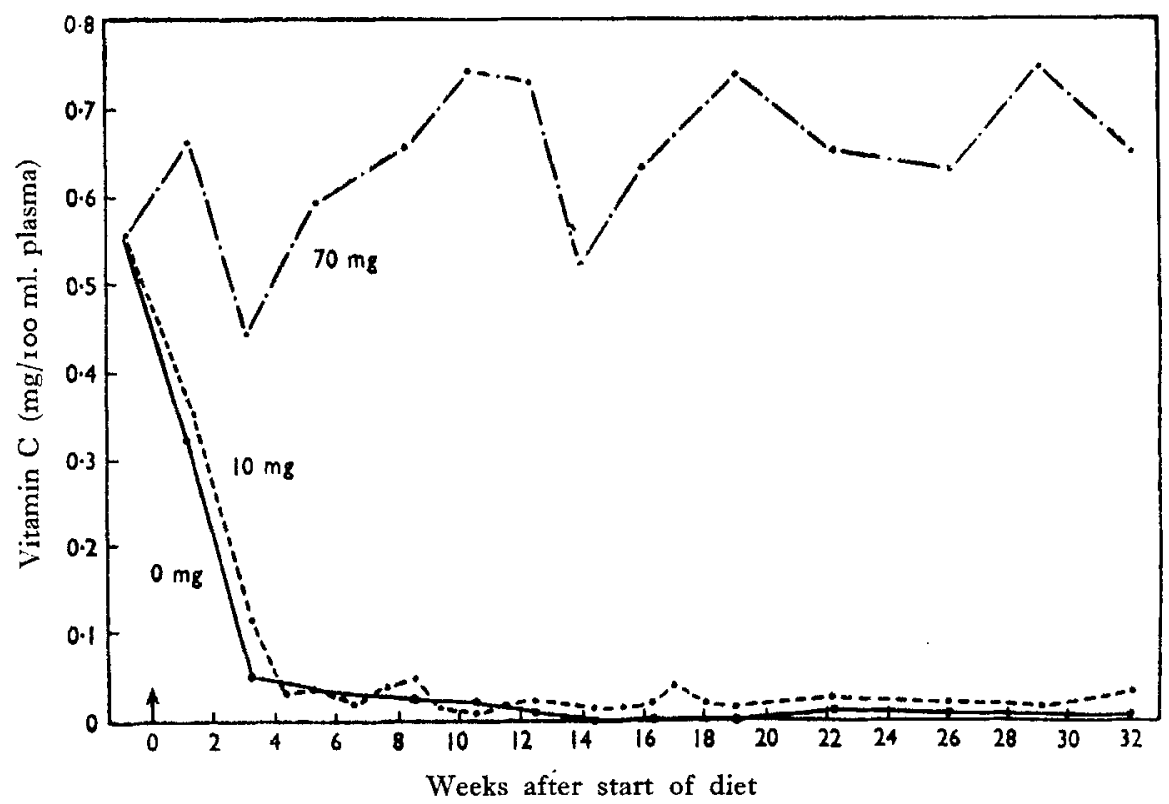

Fig. I. Average vitamin $\mathrm{C}$ content of blood plasma of groups of volunteers receiving a daily supplement of 70 , 10, or o $\mathrm{mg}$ vitamin $\mathrm{C}$ (vitamin $\mathrm{C}$ in basal diet about I $\mathrm{mg}$ daily).

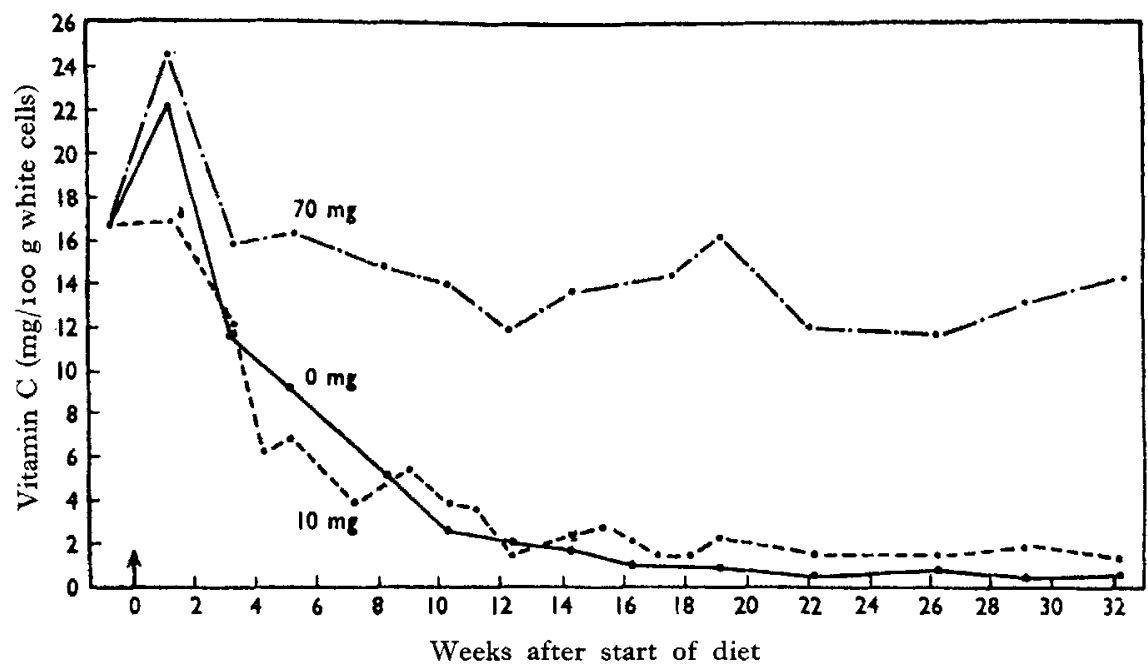

Fig. 2 Average vitamin $\mathrm{C}$ content of white blood cells of groups of volunteers receiving a daily supplement of 70,10 , or $0 \mathrm{mg}$ vitamin $\mathrm{C}$ (vitamin $\mathrm{C}$ in basal diet about I $\mathrm{mg}$ daily). 
subjects in a fasting condition. Vitamin $\mathrm{C}$ in the plasma and in the white cells (Butler \& Cushman, 1940) was estimated by the dye-titration method. The results are summarized in Figs. I and 2. The initial average plasma value for all the volunteers, at the end of the 6-week preliminary period with an intake of about $70 \mathrm{mg}$ daily, was $0.55 \mathrm{mg} / 100 \mathrm{ml}$. plasma, and this value was maintained throughout the period of the experiment by those receiving $70 \mathrm{mg}$ daily. In the totally deprived volunteers the average value was $0.03 \mathrm{mg} / 100 \mathrm{ml}$. after 37 days, and remained between 0 and $0.03 \mathrm{mg} / \mathrm{ro0} \mathrm{ml}$. for the rest of the deprivation period. In the volunteers receiving a supplement of to $\mathrm{mg}$ vitamin $\mathrm{C}$ daily the average value was $0.03 \mathrm{mg}$ after $3 \mathrm{I}$ days and fluctuated between 0.01 and $0.05 \mathrm{mg} / \mathrm{r} 00 \mathrm{ml}$. during the experimental period. Owing to the shortcomings of the analytical method no significance can be attached to the slight differences in the concentration of vitamin $\mathrm{C}$ below $0.05 \mathrm{mg} / \mathrm{I00} \mathrm{ml}$. plasma.

The initial average value of the white-cell concentration for all volunteers was $16.6 \mathrm{mg} / \mathrm{ro0} \mathrm{g}$, and was maintained at this level throughout in those receiving 70 $\mathrm{mg}$ vitamin $\mathrm{C}$ daily. In the totally deprived group it fell to $\mathrm{I} \mathrm{mg} / \mathrm{I} 00 \mathrm{~g}$ in $\mathrm{I} / 3$ days, and remained below this value for the remainder of the period. For concentrations below $2 \mathrm{mg} / \mathrm{roo} \mathrm{g}$ white cells the method is not very accurate, and differences between $\circ$ and $2 \mathrm{mg} / \mathrm{roo} \mathrm{g}$ are of doubtful significance. The average concentration of the vitamin $\mathrm{C}$ in the white cells of the volunteers receiving a supplement of 10 $\mathrm{mg}$ vitamin $C$ daily attained a value between $1 \cdot 5$ and $3 \mathrm{mg} / 100 \mathrm{~g}$ in 86 days, and from the rogth day onwards remained roughly $\mathrm{I} \mathrm{mg} / \mathrm{I00} \mathrm{g}$ above the figure of the deficient group.

Thus about 100 days elapsed between the virtual disappearance of vitamin $\mathrm{C}$ from the plasma and the first clinical signs of scurvy. On the other hand, the concentration of vitamin $C$ in the white cells reached its lowest value only $3^{-6}$ weeks before clinical scurvy appeared.

When the deficient volunteers were dosed with Io $\mathrm{mg}$ vitamin $\mathrm{C}$ daily, the concentration of the vitamin in the plasma and white cells showed a small but distinct rise towards the end of a dosing period of $10 \mathrm{I}-157$ days. The average concentration of the plasma rose from 0.016 to $0.06 \mathrm{mg} / 100 \mathrm{ml}$., and that of the white cells from below $\mathrm{I} \mathrm{mg}$ to $2.7 \mathrm{mg} / \mathrm{roo} \mathrm{g}$. Increasing the dose to $20 \mathrm{mg}$ daily produced no change in the vitamin $\mathrm{C}$ concentration of the plasma, and a slight rise in that of the white cells to $3.6 \mathrm{mg} / \mathrm{ro0} \mathrm{g}$.

It is remarkable that the concentration of vitamin $\mathrm{C}$ in plasma or white cells of persons on a prolonged intake of about I $\mathrm{mg}$ (which produced scorbutic haemorrhages after 6-8 months) is not decisively different from that of persons on an intake of about I I $\mathrm{mg}$, which over a period of 14 months prevented the appearance of the clinical signs of scurvy.

Further data on the concentration of vitamin $\mathrm{C}$ in the plasma and in the whitecell layer at different levels of intake collected during the trial are summarized in Table I. So long as the diet contained no more than $20 \mathrm{mg}$ vitamin $\mathrm{C}$ daily, the average plasma level remained below $0.10 \mathrm{mg} / 100 \mathrm{ml}$. At higher levels of intake the concentration of the vitamin in the plasma rose. A concentration of about 
Table I. Vitamin $C$ content of plasma and white cells in relation to vitamin $C$ intake

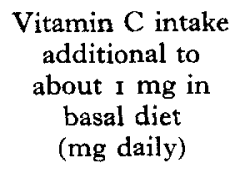

About 600
Average vitamin $\mathrm{C}$ concentration in

$\begin{array}{cc}\begin{array}{c}\text { Plasma } \\ (\mathrm{mg} / \mathrm{ro0} \mathrm{ml})\end{array} & \begin{array}{c}\text { White cells } \\ (\mathrm{mg} / \mathrm{r} 00 \mathrm{~g})\end{array} \\ <0.03 & <\mathrm{r} .0 \\ <0.05 & 2.0 \\ <0.10 & 2.7 \\ <0.10 & 3.6 \\ 0.31 & 8.6 \\ 0.55 & 10.0 \\ 1.02 & 17.0\end{array}$

$0.30 \mathrm{mg} / \mathrm{r} 00 \mathrm{ml}$. corresponded to an intake of $50 \mathrm{mg}$ daily, and of about $0.55 \mathrm{mg} /$ I00 $\mathrm{ml}$. to an intake of $70 \mathrm{mg}$ daily (compare Thysell, 1939).

For assessing the state of vitamin $\mathrm{C}$ nutrition it appears that in a fasting person a plasma value below $0.10 \mathrm{mg} / 100 \mathrm{ml}$. indicates an average daily intake in the region of $20 \mathrm{mg}$. If, therefore, in a doubtful case of scurvy the plasma level is $0.10 \mathrm{mg} / \mathrm{roO}$ $\mathrm{ml}$. or more, the existence of scurvy is very improbable, since the intake of $20 \mathrm{mg}$ daily, necessary to maintain a plasma level of $0.10 \mathrm{mg} / 100 \mathrm{ml}$., was found to be an adequate curative dose. On the other hand, a plasma level of below $0.10 \mathrm{mg} / 100 \mathrm{ml}$., though an accompaniment of scurvy, is not proof of scurvy or of imminent scurvy. The main clinical use of the plasma value for vitamin $C$, therefore, is to exclude rather than to confirm the diagnosis. To make the plasma analysis more useful, a method is required which distinguishes accurately vitamin $\mathrm{C}$ levels between 0 and $0.10 \mathrm{mg} / 100 \mathrm{ml}$.

The findings suggest that the determination of vitamin $\mathrm{C}$ in the white cells may be of somewhat greater diagnostic value, because it shows more definite differences between the intake levels of $20 \mathrm{mg}$, Io $\mathrm{mg}$, and less than $5 \mathrm{mg}$, daily. A concentration below $2 \mathrm{mg} / \mathrm{roO} \mathrm{g}$, especially when confirmed on repeated analyses, indicates severe depletion and would support the diagnosis of scurvy.

\section{Saturation tests}

Towards the end of the trial four groups of individuals were available whose different intakes of vitamin $\mathrm{C}$ had been known for comparatively long periods. Their respective intakes were $5,10,20$ and $50 \mathrm{mg}$ above the vitamin $\mathrm{C}$ content of the basal diet. There was thus an opportunity for carrying out saturation tests on subjects whose dietary history was known to an unusually precise degree. The test consisted in giving a dose of Io $\mathrm{mg}$ vitamin $\mathrm{C} / \mathrm{kg}$ body-weight daily and determining the vitamin $\mathrm{C}$ content of the urine. The number of daily doses that produced a sharp rise in the vitamin $\mathrm{C}$ content of the urine was taken as the criterion of saturation. The results are shown in Table 2. The two subjects who had received $5^{\circ}$ mg vitamin $\mathrm{C}$ daily, showed a marked rise on the Ist day of dosing. They were therefore fully saturated. Those whose intake had been $20 \mathrm{mg}$ or less required 
Table 2. Saturation tests. Number of doses of vitamin $C$ needed to produce saturation in subjects whose previous intake of vitamin $C$ was known. (The subjects were dosed daily with Io $\mathrm{mg} / \mathrm{kg}$ body-weight given in one portion at 8 a.m. each day)

$\begin{array}{cccc}\begin{array}{c}\text { Volunteer } \\ \text { no. }\end{array} & \begin{array}{c}\text { Dose of ascorbic acid } \\ \text { just before test } \\ \text { Dmount } \\ \text { Duration } \\ \text { (mg day) }\end{array} & \begin{array}{c}\text { No. of test doses after } \\ \text { (days) }\end{array} & \begin{array}{c}\text { vhich a marked rise } \\ \text { in vitamin C content of } \\ \text { urine occurred }\end{array} \\ \text { I } & 50 & 66 & \text { I } \\ 2 & 50 & 61 & \text { I } \\ 3 & 20 & 59 & 5 \\ 4 & 20 & 55 & 4 \\ 5 & 20 & 92 & 4 \\ 6 & 20 & 47 & 4 \\ 7 & 20 & 47 & 5 \\ 8 & 20 & 92 & 6 \\ 9 & 10 & 424 & 4 \\ \text { I0 } & 10 & 424 & 5 \\ \text { I1 } & 10 & 424 & 6 \\ \text { 12 } & 10 & 157 & 5 \\ \text { 13 } & 5 & 125 & 6 \\ \text { I } & 5 & 125 & 7 \\ \text { I5 } & 5 & 125 & 5\end{array}$

four or more doses, but no sharp differences were noticeable between those with previous daily intakes of 20 , 10 or $5 \mathrm{mg}$ respectively. Thus, though the saturation test can differentiate between intakes above $20 \mathrm{mg}$ or thereabouts, it is not a method for differentiating between intake levels of $20 \mathrm{mg}$ and below, which are those of greatest practical importance. An intake of 10 or $20 \mathrm{mg}$, sufficient to cure and prevent scurvy, gives about the same results as an intake of $5 \mathrm{mg}$ which is probably below the safety level.

\section{Vitamin $C$ requirement}

The main facts relevant to the assessment of the requirement are as follows:

(I) A supplement of ro $\mathrm{mg}$ cured clinical scurvy in all six cases examined.

(2) A supplement of ro $\mathrm{mg}$ protected seven volunteers throughout the period of observation, which, for three of them, extended to 424 days.

(3) When a ro mg supplement was withdrawn from three volunteers after I 60 days and was followed by a period of 195 days during which the intake varied slightly, with an average for the three of $3.2,3.2$, and $4.5 \mathrm{mg}$ vitamin $\mathrm{C}$ daily, no definite clinical signs of scurvy appeared.

These facts suggest that in the group under test the 'minimum protective dose' of vitamin $\mathrm{C}$, as measured by the criteria of the presence of scurvy, was in the region of, perhaps somewhat below, Io $\mathrm{mg}$ daily.

Distinct from the 'minimum protective dose' for a particular group of people, in this case a few normal young adults leading a life without strenuous physical work, is 'the larger figure which shall cover the requirement of normal adults with 
their own inherent variability enhanced by the variety of their activities and environment and ensure for them the margin of protection at which it is decided to aim' (Hume \& Krebs, I949). To satisfy these ill-defined additional needs and to allow a margin of safety it does not therefore seem too generous to treble the minimum protective dose of Io $\mathrm{mg}$, which prevents clinical scurvy, and thereby confirm the figure of $30 \mathrm{mg}$ vitamin $\mathrm{C}$ daily recommended by the League of Nations Health Organization: Technical Commission on Nutrition (1938) for the requirement of a normal human adult.

Any assessment is, at the present state of knowledge, a matter of judgement and must be regarded as provisional. The present assessment has a firmer basis than previous estimates in that it rests on the determination of the minimal protective dose for a group of human beings. The new estimate is considerably below the allowance of $75 \mathrm{mg}$ recommended by the (U.S.A.) National Research Council: Food and Nutrition Board (1943), which is essentially the amount necessary to maintain 'saturation'; but, so long as there is no evidence to support the view that an intake of more than $30 \mathrm{mg}$ daily has beneficial effects, there is no basis for recommending an intake greater than that amount.

When the figure of $30 \mathrm{mg}$ daily is used, for whatever purpose, it should be borne in mind how it was assessed. It is obvious that intakes much below the recommended figure, which are reflected in a plasma concentration of vitamin $\mathrm{C}$ not distinguishable from a scorbutic one, are not necessarily detrimental to health.

In conclusion I must pay tribute to the young men and woman who volunteered to act as human 'guinea-pigs'. The majority were conscientious objectors who had convictions which did not allow them to carry arms, but who did not wish to eschew hardship and danger. They offered themselves to serve a cause they considered good. They were fully aware of the nature of the trial and of the risks it involved. When the Committee decided on account of the cardiac incidents to shorten the period of deprivation in certain cases the volunteers let it be known as their wish that considerations for their personal safety should not stand in the way of pursuing the object of the trial. Fortunately they suffered only temporary disabilities. No permanent harm was done.

\section{REFERENCES}

Bartley, W., Krebs, H. A. \& O'Brien, J. R. P. (1953). Spec. Rep. Ser. med. Res. Contn., Lond., no. 280. Butler, A. M. \& Cushman, M. (1940). F. clin. Invest 19, 459.

Göthlin, G. F. (1931). Skand. Arch. Physiol. 6r, 225.

Hess, A. F. (1920). Scurvy, Past and Present. Philadelphia: Lippincott.

Hume, E. M. \& Krebs, H. A. (1949). Spec. Rep. Ser. med. Res. Coun., Lond., no. 264.

League of Nations Health Organization: Technical Commission on Nutrition (1938). Bull. Hlth Org. L.o.N. 7, 460 .

Lind, J. (I757). A Treatise of the Scurvy, and ed. London: Millar.

Medical Research Council: Vitamin C Subcommittee of the Accessory Food Factors Committee (1948). Lancet, 254, 853 .

National Research Council: Food and Nutrition Board (I943). Repr. nat. Res. Coun., Wash., No. I 5.

Thysell, T. (1939). Acta paediatr., Stockh., 26, 48 r.

Zilva, S. S. (r94 I). Biochem. F. 35, r240.

Zilva, S. S. (r944). Brit. med. Bull. 2, 2 r 7. 